\title{
The Effect of Pasteurization on Microbial Growth and Sensory Qualities of Sekete - a fermented maize beverage
}

\author{
${ }^{1 *}$ Onaolapo I.O., ${ }^{1}$ Busari T. \\ ${ }^{I}$ Department of Applied Sciences, Osun State Polytechnic, Iree, Nigeria
}

\begin{abstract}
The microbial load and sensory qualities of sekete were investigated with a view to improving on its shelf-life and commercializing its production. The samples were subjected to varying pasteurizing temperatures namely $65^{\circ} \mathrm{C}$ for 30minutes, $70^{\circ} \mathrm{C}$ for 30 minutes and $75^{\circ} \mathrm{C}$ for 30 minutes. The microbial load of each pasteurized sample was determined at weekly interval. Organoleptic properties of freshly pasteurized samples and those that stored at ambient temperature were evaluated. The samples pasteurized at $65^{\circ} \mathrm{C}$ for 30minutes had highest bacterial load increasing from $4.0 \times 10^{1}$ (first week) to $2.0 \times 10^{2} \mathrm{cfu} / \mathrm{ml}$ (fourth week) while samples pasteurized at $70^{\circ} \mathrm{C}$ for 30minutes had bacterial load ranging from $1.0 \times 10^{1} \mathrm{cfu} / \mathrm{ml}$ (first week) to $2.0 \times 10^{1} \mathrm{cfu} / \mathrm{ml}$ (fourth week). There was no bacterial growth in the sample pasteurized at $75^{\circ} \mathrm{C}$ for 30minutes. There was no yeast growth in all samples throughout the storage time. The results of sensory qualities revealed that samples were not significantly different $(p=0.05)$ except in taste. It can be concluded that the pasteurization condition studied effectively extended the shelf life of the sekete for four weeks.
\end{abstract}

Keywords: Sekete, Pasteurization, Shelf-life, Fermentation.

\section{Introduction}

In sub-Saharan African, most traditional alcoholic and non-alcoholic beverages are produced from cereals.Pitoand Burukutuare alcoholic beverages brewed from guinea corn.Kunuzaki, a non-alcoholic beverage, is also produced from guinea corn. Sekete, a local beverage of low alcohol content is produced from malted maize grains (Faparusiet al., 1991, Aderinto, 2004 and Osuntogun and Aboaba, 2007). These beverages apart from serving as intoxicating drinks are also important in fulfilling social functions like marriage and burial ceremonies (Sanni and Lonner, 1993). Their productions rely on spontaneous fermentation by yeasts and lactic acid bacteria. Alcoholic fermentation is due to metabolic activity of yeasts while bacteria is noted for lactic acid fermentation (Faparusiet al., 1973; Ogundero and Fapohunda, 1987 and Sefadedahet al., 1999).Pitois an alcoholic beverage common among the people of Nigeria, Ghana and Togo (Damuyakor and Ohta, 1991). It is golden yellow to dark brown with taste varying from slightly sweet to very sour. This beverage contains, lactic acid, sugar, amino acid, 2-3\% alcohol, some vitamins and proteins (Ekundayo, 1969). Burukutuis a popular alcoholic beverage in northern Guinea Savana region, Benin Republic and Ghana (Wood, 1984). The premium burukutuis a cloudy liquid with vinegar taste and odor (Faparusiet al., 1973). Kunuzakihas about $70.3 \%$ starch, $11.6 \%$ protein, $3.3 \%$ fat, $1.9 \%$ ash and wide range of amino acid (Lichtenealneret al., 1979).Sekete is an opaque maize beverage produce from maize grains in South Western part of Nigeria (Odunfa, 1985). Traditionally it is produced from maize by steeping in water, draining and air drying in a clay pot lined with banana leaves. The grain are then moistened for 3 or 5 days for germination and grounded with mortar. The resulting coarse particles are mixed with water at ratio of 1:2 in a pot. The mixture obtained is cooled, filtered, reheated for about 15min and boiled as sekete(Sawyer, 1988). Ogundero and Fapohunda(1987), produced sekete in the laboratory by steeping maize grains in a water for $48 \mathrm{~h}$, malting for 3 days,air drying of malted grains for 2 days, kilning for $24 \mathrm{~h}$ at $80^{\circ} \mathrm{C}$, milling and filtrating through 0.55 micrometre sieve and fermenting for 3-4 days. Lueconostoc,Mesenteroides, Pediococcuscerevisaea,Streptococcusspp.,Lactobacillus planetarium and Staphylococcus aureusare bacteria responsible for fermentation while Saccharomyces rouxii, Geotricumcandidum, are yeast responsible for fermentation (Adegokeet al., 1995).Physiochemically, 48h fermented maize beverage contains $30.9 \%$ of dry malter, $3.6 \%$ ash, $\mathrm{pH} 4.2$, titratable acidity $0.9 \%$ and alcohol content of 4\% (Adegokeet al., 1995).Pasteurization, a term given to heat process typically in the range of 60$80^{\circ} \mathrm{C}$ and applied for up to a few minutes, is used for two purposes. First, is the elimination of a specific pathogen or pathogenic associated with a product. The second reason for pasteurizing a product, is to eliminate a large proportion of potential spoilage organism thus extending its shelf-life (Adams and Moss, 1997). Different pasteurization temperature, have been discovered to be effective against both spoilage and pathogenic bacterial. Pasteurization temperatures of $75^{\circ}$ for 30 minutes with treatment of $0.5 \mathrm{~g} / \mathrm{L}$, of sorbic acid was proved to be more effective in checking microbial growth than others pasteurization temperature $\left(68^{\circ} \mathrm{C}\right.$ for $10-3 \mathrm{~min}$ and $70^{\circ} \mathrm{C}$ for 10 to 20min) in the preservation of pito (Damuyokor and Ohta, 1991). Majiet al., (2011) extended shelf-life of pasteurized kunuzaki $\left(\right.$ at $60^{\circ} \mathrm{C}$ ), a traditional fermented cereal based non-alcoholic beverage, with or without sodium benzoate or sodium metabisulphite $(0.1 \%)$ for more than 2 weeks. Among the many challenges of 
traditional processed food products in Nigeria are that processing method are crude, manual and of unsanitary conditions hence product are of unpredictable quality (Okafor, 1983). Many of the locally prepared food have limited shelf-life of about 2-3days been susceptible to contaminating yeasts, mold and bacterial which end up deteriorating the quality of foods. The aim of this work is to determine the effect of different pasteurization temperatures on the microbial and physicochemical qualities of maize beverage.

\section{Materials And Methods}

\section{Sample Preparation}

White maize grains were purchased at the main market, Ile-Ife, Nigeria and screened thereafter to remove broken grains and foreign materials.

\section{Laboratory Processing of Maize Beverage}

The method of Adegokeet al., (1995) was employed in which the maize grains were steeped in $2 \%$ solution of formaldehyde for $24 \mathrm{~h}$, during which steep water was changed intermittently at every $6 \mathrm{~h}$. The steeped grains were spread on mat for 4 days for malting. During which the grains were humidified with solution of formaldehyde $(2 \%)$ and turned at regular intervals. The malted grains were wet-milled thereafter a slurry of it was made with 3 volume of water and allowed to ferment for $96 \mathrm{hs}$. This was followed by sieving. The resulting filtrate $(100 \mathrm{ml})$ was bottled and pasteurized at different temperatures of $65^{\circ} \mathrm{C}, 70^{\circ} \mathrm{C}$ and $75^{\circ} \mathrm{C}$ for 30 minutes (see Fig. 1.0).

\section{Enumeration of Microorganisms in the Pasteurized Samples}

Samples of maize beverage (keeping of room temperature) were taken in weekly intervals for enumeration. The samples were aseptically dispensed into sterile screw capped bottles. Pour plate technique was used to determine microbial number in colony forming unit per $\mathrm{ml}(\mathrm{cfu} / \mathrm{ml})$. Serial dilution of each sample was made up to $10^{-6}$ and each diluted samples, $1 \mathrm{ml}$ was aseptically introduced into each of the sterile petri dishes. Different molten media were added at different times and mixed.

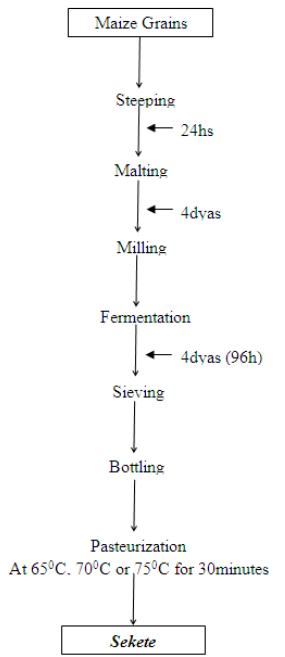

Fig. 1.0: Process flow chart for the laboratory production of fermented maize beverage (Sekete)

With the content of each petri dish. Following proper mixing of medium with sample, each plate was allowed to set before incubation. Nutrient agar was used for aerobic bacterial counts while acidified potato dextrose agar (PDA) was used for yeast counts. The bacterial counts were determined after $24 \mathrm{~h}$ of incubation at $37^{\circ} \mathrm{C}$ while yeast counts were determined at $48 \mathrm{~h}$ of incubation at $29^{\circ} \mathrm{C}$. The control plates were prepared as in the that of experimental plates except that sample from which inoculums was obtained was not pasteurized (Harrigen, 1998).

\section{Sensory Evaluation}

Samples of freshly pasteurized maize beverages were presented to a panel of judges who were familiar with locally brewed beverage. Using 9 - point Hedonic scale (where I and 1 represent dislike extremely and like extremely respectively). The panelists were asked to evaluate the samples for appearance, colour, aroma overall acceptability and taste. The scores were subjected to analysis of variance and Turkey's test was employed to determine the degree of difference among the samples where necessary (Ihekoronye and Ngoddy, 1985). 
The Effect of Pasteurization on Microbial and Sensory Qualities of Sekete - a fermented ....

\begin{tabular}{|c|c|c|c|c|c|}
\hline \multicolumn{6}{|c|}{ Aerobic Bacteria Counts of Maize Beverage (Sekete) } \\
\hline \multirow[t]{3}{*}{ Storage Time } & \multicolumn{5}{|c|}{ Aerobic bacteria counts } \\
\hline & \multicolumn{3}{|c|}{ Pasteurized Samples } & \multicolumn{2}{|c|}{ Unpasteurized Samples } \\
\hline & $65^{0} \mathrm{C} / 30$ & $\mathbf{7 0}^{\circ} \mathrm{C} / 30$ & $7^{\circ} \mathrm{C} / 30$ & Bacteria Count & Yeast Count \\
\hline FBS & $4.0 \times 10^{1}$ & $1.0 \times 10^{1}$ & Nil & $2.68 \times 10^{7}$ & $5.3 \times 10^{6}$ \\
\hline $2^{\text {nd }}$ week & $1.1 \times 10^{2}$ & $1.0 \times 10^{1}$ & Nil & $5.15 \times 10^{7}$ & $6.0 \times 10^{8}$ \\
\hline $3^{\text {rd }}$ week & $1.7 \times 10^{2}$ & $1.3 \times 10^{1}$ & Nil & $1.15 \times 10^{12}$ & $7.0 \times 10^{12}$ \\
\hline $4^{\text {th }}$ week & $2.0 \times 10^{2}$ & $2.0 \times 10^{1}$ & Nil & $1.60 \times 10^{15}$ & $1.8 \times 10^{14}$ \\
\hline
\end{tabular}

FBS $=$ Freshly bottle samples

$60^{\circ} \mathrm{C} / 30 \mathrm{~min}=$ Pasteurized samples at $65^{\circ} \mathrm{C}$ for $30 \mathrm{~min}$

$70^{\circ} \mathrm{C} / 30 \mathrm{~min}=$ Pasteurized samples at $70^{\circ} \mathrm{C}$ for $30 \mathrm{~min}$

$75^{\circ} \mathrm{C} / 30 \mathrm{~min}=$ Pasteurized samples at $75^{\circ} \mathrm{C}$ for $30 \mathrm{~min}$

Table 2 Mean of Sensory Scores of Maize Beverage

\begin{tabular}{|c|c|c|c|}
\hline & \multicolumn{3}{|c|}{ Pasteurized Samples } \\
\hline & $\begin{array}{l}\text { Pasteurized samples at } 65^{\circ} \mathrm{C} \text { for } \\
\text { 30minutes }\end{array}$ & $\begin{array}{l}\text { Pasteurized samples at } 70^{\circ} \mathrm{C} \text { for } \\
\text { 30minutes }\end{array}$ & $\begin{array}{l}\text { Pasteurized samples at } 75^{\circ} \mathrm{C} \text { for } \\
\text { 30minutes }\end{array}$ \\
\hline Taste & $4.6 \mathrm{ab}$ & $4.3 \mathrm{bb}$ & $4.64 \mathrm{bb}$ \\
\hline Colour & $5.4 \mathrm{a}$ & $5.6 \mathrm{a}$ & $5.2 \mathrm{a}$ \\
\hline Aroma & $5.3 \mathrm{a}$ & $5.1 \mathrm{a}$ & $5.1 \mathrm{a}$ \\
\hline Appearance & $5.7 \mathrm{a}$ & $5.5 \mathrm{a}$ & $5.7 \mathrm{a}$ \\
\hline $\begin{array}{l}\text { Over all } \\
\text { Acceptability }\end{array}$ & $5.3 \mathrm{a}$ & $5.4 \mathrm{a}$ & $5.3 \mathrm{a}$ \\
\hline
\end{tabular}

Mean with the same letter are not significantly different at $\mathrm{p}=0.05$ probability level.

\section{Results And Discussion}

The result of bacterial load showed that bacterial number decreased with the increase in pasteurization temperatures during four week of storage at ambient temperature. The samples pasteurized at $65^{\circ} \mathrm{C}$ for 30minutes had the highest bacterial load, it increased from $4.0 \times 10^{1} \mathrm{cfu} / \mathrm{ml}$ (first week) to $2.0 \times 10^{2} \mathrm{cfu} / \mathrm{ml}$ (fourth week). The result of samples pasteurized at $70^{\circ} \mathrm{C}$ for 30 minutes followed the same pattern as former but had very low bacterial load, it increased from $1.0 \times 10^{1} \mathrm{cfu} / \mathrm{ml}$ (first week) to $2.0 \times 10^{1} \mathrm{cfu} / \mathrm{ml}$ (fourth week). No bacterial was observed in the beverage pasteurized at $75^{\circ} \mathrm{C}$ for 30 minutes throughout the week of storage. There was no yeast growth in all the pasteurized samples during the time of storage while there were marked increase in microbial load in the unpasteurized samples (Table 1 and 2). The absence of yeast during storage might be due to higher sensitivity of yeast to temperature than bacteria (Frazier and Westoff, 1995). The decreased bacterial load with increase in pasteurization temperature might be attributed to thermosensitivity of spoilage and pathogenic bacteria (Prescotet al., 2007) and may also be due to decreased $\mathrm{pH}$ and increased acidity of samples (Frazier and Westoff, 1995). Result of sensory evaluation of beverages showed that was no significant difference $(\mathrm{p}=0.05)$ among the samples in appearance colour, aroma and overall acceptability but in taste sample pasteurized at $65^{\circ} \mathrm{C}$ for 30minutes was preferred to others while there was little or no different in taste of others (see Table 3 ).

The results of these findings are in agreement with works of previous researchers: Damuyakor and Ohta (1991), revealed that combination of pasteurizing temperature of $75^{\circ} \mathrm{C}$ for $30 \mathrm{~min}$ and sorbic acid $(0.5 \mathrm{~g} / \mathrm{L})$ were effective in checking microbial proliferation than pasteurization temperatures of $68^{\circ} \mathrm{C}$ for $10-30,70^{\circ} \mathrm{C}$ for $10-20 \mathrm{~min}$ and $75^{\circ} \mathrm{C}$ for $10-20 \mathrm{~min}$, Egbereet al., (2007), reported that pasteurizing zobo drink (a non-alcoholic beverage) at $70^{\circ} \mathrm{C}$ for $25 \mathrm{~min}$ with or without sodium benzoate were effective in eliminating. Escherichia coli and Staphylococcus aureus(pathogenic bacteria) from zobo drink, Osuntogun and Aboaba (2004), depicted that pasteurization temperature of $72^{\circ} \mathrm{C}$ for 15 minutes was enough to produce shelf stable Ginger beer, soya milk, and soborodo drink (non-alcoholic beverages) without compromising their physico-chemical properties of the products, Nebedum and Obako (2004), proved that pasteurization temperature of $\left(62.8^{0} \mathrm{C}\right.$ for $\left.30 \mathrm{~min}\right)$ could reduce microbial growth but not however effective as sodium benzoate and benzoic acid (chemical preservatives) in extending shelf life of Nunu (Local yoghurt).Ojimelikweet al., 2013, reported that the combination of pasteurization with ginger/sodium metabisulphite could decrease microbial load and enhance the quality kunuzakiduring storage and hence extending its shelf-life.

\section{Conclusion}

In conclusion, all the investigated pasteurization temperatures are suitable in checking proliferation of spoilage and pathogenic bacterial and yeasts effectively and thus extending shelf-life of beverage without compromising its physico-chemical parameters but the most suitable pasteurization temperature is to pasteurize at $75^{\circ} \mathrm{C}$ for 30 minutes. 


\section{References}

[1]. Adam, M.R. and Moss, M.O. (1997). Pasteurization and Appertization in: Food microbiology, Thomas Graham House U.K. 56-58.

[2]. Adegoke, G.O., Nwaigwe, R.N., Oguntimein G.B. (1995). Microbiological and Biochemical changes during production of sekete, a fermented beverage from maize, Journal of Food science and Technology, 32: 516-518.

[3]. Aderinto G.A. (2004). Microbiology of Otika, an indigenous fermented beverage.Journal of Bio

[4]. AOAC (2000). Official method of analysis.Association of analytical chemists Washington, D.C.

[5]. Damuyakor, B. and Ohta, Y. (1991).Characteristic of Pitoyeast from Ghana Food Microbiology, 8: 183-193.

[6]. Egbere, O.J., Anuonye, O.B., Chollom, P.F. and Okpara, P.V. (2007). Effect of some preservation technique on the quality and storage stability of Zobodrink (A Nigerian and non-alcoholic beverage from Hibiscus sabodariffa) Journal of food tech., 5(3): 225-228.

[7]. Ekundayo, J.A. (1969). The production of pito, a Nigerian Fermented Beverage, Journal of Food

[8]. Faparusi, S.I., Olofintoba, M.O. and Ekundayo, J.A. (1973).The Microbiology of burukutubeer.

Technol., 4: 17-25.

Z. Allg. Mikrobiologue, 13: 563-568

[9]. Frazier, W.E. and Westhoff, O.F. (1978).Food microbiology $3^{\text {rd }}$ Ed. McGraw Hill Book

C.O.N.Y

[10]. Harrigan, W.F. and McCance, M. (1976).Laboratory method in food and dairy microbiology

[11]. Ihekoronye, A.L. and Ngoddy, P.O. (1985).Integrated food science and tech. for the Tropics. London.

[12]. Lichtenwainer, R.E., Glover, G.L. and Shaw, C.C. (1979). Protease activity of water and acid, grain, their changes during malting and their anti-inhibitory nature. J. Agric. Food Chem., 30: 450-456.

[13]. Maji, A.A., James O. and Chigozie O.E. (2011).Effect of chemical treatment and pasteurization kunuzaki(soughum and maize grain) Eur. Journal of Food Research and Rev. 1(2): 61-20.

[14]. Nebedum, J.O. and Obiaro, T. (2007). The effect of different preservation method on the quality Nigerian dairy product.Africa Jour. Of Biotech.,6(4): 454- 458

[15]. Odunfa, S.A. (1985). African fermented food in: Microbiology of fermented foods, $2^{\text {nd }}$ ed., Wood B.J.B. Elsevier Applied Sci. pub. London and N.Y., 155-157.

[16]. Ogundero, O. and Fapohunda, S. (1987). The mycoflora of fermenting maize (zeamay) Grains Nig. Food Journal, 21: 65-68

[17]. Ojimelukwe, I.P., Elijah, Ekong, S.U. and Nwokorcha, I.K. (2013). The effect of physiochemical treatment (Freezing, ohmic heat treatment, pasteurization, acidification, sodium metabisulphite) and botanical (ginger extract) preservative on shelf-life of a traditional fermented cereal based non-alcoholic beverage: Kunu-zaki, Nig. Journal of Food and Environ. 9(1): 76-79.

[18]. Okafor, N. (1983). Processing of indigenous fermented food: A chance for innovation Nig. Food, 1: $32-37$

[19]. Osuntogun, B. and Aboaba, O.O. (2004). Microbiology and physico-chemical evaluation of some non-alcoholic beverages, Journal of Nutrition, 3(3): 188-192.

[20]. Sanni, A.I. and Lonner, C. (1993). Identification of yeast isolated from Nig. Traditional alcoholic beverages. Food Microbiology, 10: 517-523.

[21]. Sawyer, O.A. (1988).Microbiology and other characteristics of jogi, Ekuruand sekete.M.Sc. Thesis, University of Ibadan, Ibadan

[22]. Sefa-Dedah, S., Sanni, A.I., Tetteh, G. and Sakyi-Dawson, E. (1999).Yeast in the brewing of of Microbiology and Biotechnology, 15: 593-597.

[23]. Wood, B.J.B. (1984). Progress in so source and related fermentation. In industrial microbiology $\quad$ 19: Ed. Bushell M.E. Elsevier Amsterdam, 373-410. 